\title{
Clinical Utility of Molecular Diagnosis of Blood Stream Infections in Allogeneic Hematopoietic Stem Cell Transplantation Recipients with Hematologic Malignancies
}

\author{
Atsushi Fujieda1, Kazunori Nakase2 ${ }^{2}$ Akiko Nakamura3 ${ }^{3}$ Kohshi Ohishi', \\ Yuka Sugimoto $^{1}$, Fumihiko Monma ${ }^{1}$, Masahiro Masuya ${ }^{1}$, Naoyuki Katayama ${ }^{1}$ \\ ${ }^{1}$ Department of Hematology and Oncology, Mie University Hospital, Tsu, Japan \\ ${ }^{2}$ Cancer Center, Mie University Hospital, Tsu, Japan \\ ${ }^{3}$ Central Clinical Laboratories, Mie University Hospital, Tsu, Japan \\ ${ }^{4}$ Transfusion Service, Mie University Hospital, Tsu, Japan \\ Email:k2nakase@clin.medic.mie-u.ac.jp
}

How to cite this paper: Fujieda, A., Nakase, K., Nakamura, A., Ohishi, K., Sugimoto, Y., Monma, F., Masuya, M. and Katayama, N. (2019) Clinical Utility of Molecular Diagnosis of Blood Stream Infections in Allogeneic Hematopoietic Stem Cell Transplantation Recipients with Hematologic Malignancies. Advances in Microbiology, 9, 971-982.

https://doi.org/10.4236/aim.2019.912062

Received: November 6, 2019

Accepted: December 3, 2019

Published: December 6, 2019

Copyright (๑) 2019 by author(s) and Scientific Research Publishing Inc. This work is licensed under the Creative Commons Attribution International License (CC BY 4.0).

http://creativecommons.org/licenses/by/4.0/

\section{c. (i) Open Access}

\begin{abstract}
Blood stream infections (BSIs) are a serious problem in patients with hematologic malignancies receiving allogeneic hematopoietic stem cell transplantation (ASCT). We evaluated the clinical utility of molecular diagnosis for the management of BSIs in such patients. We prospectively performed a polymerase chain reaction (PCR) analysis of microbial DNA in blood samples from 10 consecutive patients with hematological malignancies at least once a week for one month after ASCT. In total, 51 and 54 samples were analyzed by bacterial and fungal PCR assays, respectively. Bacteria were detected in 24 samples from 8 patients by PCR, but in only 2 samples from one patient by blood culture. Notably, the bacteria detected in at least half of the 24 samples were considered to have originated from the oral cavity. Fungi were detected in 5 samples from 3 patients by PCR, but not by blood culture. Most cases with positive PCR results were manageable with empirical antimicrobial therapy without disclosure of DNA data. Our DNA analyses did not directly contribute to management of BSIs, but did provide valuable microbiological evidence for the patients. Additionally, oral management appears to require a critical re-evaluation to reduce the occurrence of BSIs in ASCT recipients.
\end{abstract}

\section{Keywords}

Allogeneic Hematopoietic Stem Cell Transplantation, Blood Stream Infection, PCR Analysis 


\section{Introduction}

Allogeneic hematopoietic stem cell transplantation (ASCT) offers the chance of cure for patients with hematologic malignancies. However, blood stream infections (BSIs) are major causes of morbidity and mortality for patients undergoing ASCT [1]. Therefore, successful management of these infectious complications is essential to further improve the clinical outcome of such patients. BSIs commonly develop early after ASCT despite the use of prophylactic anti-infective drugs [1] [2]. However, conventional blood culture (BC), which is the gold standard for identifying causative pathogens, has a low isolation rate and is very time-consuming [3]. At present, there is no solution for BSI management other than empirical antimicrobial therapy despite the lack of microbiological evidence in a majority of ASCT recipients. On the other hand, polymerase chain reaction (PCR)-based analysis of microbial DNA is a promising tool for the sensitive and rapid detection of etiological organisms [3] [4]. PCR assays are reportedly useful in managing febrile neutropenia in patients with hematologic disorders [5] [6]. To our knowledge, however, these molecular techniques have not been well evaluated in hematologic patients undergoing ASCT.

In this study, we prospectively applied an original PCR assay to find causative organisms in peripheral blood (PB) samples of patients with hematologic malignancies who had received ASCT, and we evaluated its clinical usefulness for managing BSIs. Our DNA data provide valuable microbiological information for the management to reduce the occurrence of BSIs in ASCT recipients.

\section{Materials and Methods}

\subsection{Patients and Definitions}

Patient characteristics are shown in Table 1 . Ten consecutive patients (median age, 44 yr.; range, 19 - 62 yr.) with hematologic malignancies who had undergone ASCT in our institution were enrolled. This prospective study was approved by the Human Research Ethics Committee of Mie University (Tsu, Japan), and was in accordance with the current version of the Helsinki Declaration. Written informed consent was obtained from all patients recruited. Eight patients received total body irradiation (TBI)-based conventional preconditioning regimen and 2 received reduced-intensity preparative regimens. Graft-versushost disease (GVHD) prophylaxis was either cyclosporine or tacrolimus, which was combined with a short course of methotrexate. All patients were housed in rooms equipped with a high-efficiency particulate air system, and standard precautions were used for all patients care. They received antibacterial prophylaxis with fluoroquinolone and antifungal prophylaxis with mold-active azoles, such as itraconazole (ITCZ) or voriconazole (VCZ), with temporary use of micafungin during the preconditioning period. Prophylaxis against herpes virus infection was also given with acyclovir. We performed PCR analyses of bacteria and fungi from fresh PB samples at least once weekly for the first 30 days after ASCT. Diagnosis of invasive fungal disease was made according to the revised classification of 
Table 1. Patient characteristics and conditioning regimen.

\begin{tabular}{|c|c|c|c|c|c|c|c|}
\hline $\begin{array}{l}\text { Patient } \\
\text { no. }\end{array}$ & Age/Sex & $\begin{array}{l}\text { Underlying } \\
\text { disease }\end{array}$ & $\begin{array}{c}\text { Status at } \\
\text { transplantation }\end{array}$ & Conditioning & $\begin{array}{l}\text { Stem cell } \\
\text { source }\end{array}$ & GVHD prophylaxis & $\begin{array}{c}\text { Prophylactic } \\
\text { antibiotics }\end{array}$ \\
\hline 1 & 49/male & ATLL & CR1 & TBI $(12 \mathrm{~Gy})+\mathrm{CY}$ & UR-BM & Tacrolimus + sMTX & LVFX \\
\hline 2 & $44 /$ male & AML & CR1 & Flu + BU + TBI (2 Gy) & UR-BM & Tacrolimus + sMTX & - \\
\hline 3 & $20 /$ male & ALL & CR1 & TBI $(12 \mathrm{~Gy})+\mathrm{CY}$ & Rel-PB & Ciclosporin + sMTX & TFLX \\
\hline 4 & $45 /$ female & ALL & CR2 & TBI (12 Gy) + CA + CY & UR-CB & Tacrolimus + sMTX & LVFX \\
\hline 5 & $44 /$ male & LBL & PR1 & TBI $(12$ Gy $)+\mathrm{CA}+\mathrm{CY}$ & UR-CB & Tacrolimus + sMTX & LVFX \\
\hline 6 & $44 /$ male & MDS & CR1 & $\mathrm{TBI}(12 \mathrm{~Gy})+\mathrm{CA}+\mathrm{CY}$ & UR-CB & Tacrolimus + sMTX & LVFX \\
\hline 7 & $62 /$ male & ALL & CR2 & Flu + Mel + TBI (4 Gy) & UR-CB & Tacrolimus + sMTX & LVFX \\
\hline 8 & $24 /$ male & AML & CR2 & TBI $(12 \mathrm{~Gy})+\mathrm{CY}$ & UR-BM & Tacrolimus + sMTX & LVFX \\
\hline 9 & $46 /$ male & ATLL & CR1 & TBI $(12 \mathrm{~Gy})+\mathrm{CY}$ & Rel-PB & Ciclosporin + sMTX & CPFX \\
\hline 10 & $19 /$ male & ALCL & primary refractory & TBI $(12 \mathrm{~Gy})+\mathrm{CY}$ & UR-BM & Tacrolimus + sMTX & LVFX \\
\hline
\end{tabular}

$A T L L$ adult T-cell leukemia/lymphoma, $A M L$ acute myeloid leukemia, $A L L$ acute lymphoblastic leukemia, $L B L$ lymphoblastic lymphoma, $M D S$ myelodysplastic syndrome, $A L C L$ anaplastic large cell lymphoma, $C R$ complete remission, $P R$ patial remission, $T B I$ total body irradiation, CY cyclophosphamide, flu fludarabine, $C A$ cytarabine, $M e l$ melphalan, $U R-B M$ unrelated bone marrow, Rel-PB related peripheral blood, $C B$ cord blood, $s M T X$ short methotrexate, LVFX levofloxacin, TFLX tosufloxacin, CPFX ciprofloxacin.

the European Organization of Research and Treatment of Cancer/Mycosis Study Group (EORTC/MSG) [7]. In neutropenic $(\leq 500 / \mu \mathrm{l})$ patients at the onset of fever $\left(\geq 38^{\circ} \mathrm{C}\right)$ and in afebrile patients with neutropenia but with signs or symptoms of infection, empirical antibacterial therapy was initiated with broad-spectrum $\beta$-lactam antibiotics [cefepime, meropenem (MEPM), or doripenem (DRPM)] with or without aminoglycoside (arbekacin), and when a substantial mucosal injury occurred, a glycopeptide [vancomycin (VCM) or teicoplanin] was added [8]. As a surrogate marker for mucosal injury, we adopted the severity of stomatitis and diarrhea according to the National Cancer Institute Common Terminology Criteria for Adverse Events Scales (NCI-CTCAE) [9]. PCR results were not shared with the physicians, but were disclosed if fever continued despite empirical antimicrobial treatment and if the physician requested them. For febrile episodes, $\mathrm{BC}$ was performed as necessary. Blood samples were cultured in an automated system (BacT/Alert 3D, BioMerieux, France). Serological (1-3)- $\beta$-D-glucan (BDG) and galactomannan antigen (GM) assays were performed at least once weekly. BDG and GM were measured in each sample using the Beta-glucan test (Wako Pure Chemical Industries, Ltd., Osaka, Japan) and the Platelia ${ }^{\mathrm{Tm}}$ Aspergillus enzyme immunoassay (Bio-Rad, Marnes-la-Coquette, France), respectively. GM results were recorded as an index relative to the mean optical density of the threshold controls (GM index = optical density of sample/mean optical density of the threshold control sample). A positive GM result was defined as an index value of $\geq 0.5$. A positive BDG level was defined as a serum level of $\geq 11 \mathrm{pg} / \mathrm{ml}$.

\subsection{Molecular Detection of Bacteria and Fungi}

PCR-based molecular detection of bacterial and fungal DNA was designed to 
detect various pathogenic bacteria and fungi, and the broad range primers, which amplify a conserved region of the bacterial 16S rRNA gene and the fungal 18S rRNA gene, were used. Extraction and purification of DNA from bacteria and fungi were performed, as we previously described [6] [10]. EDTA-anticoagulated PB (1 ml) was centrifuged at $1000 \mathrm{~g}$ for $10 \mathrm{~min}$. The supernatant was used for detection of bacterial DNA, while the buffy coat was used for detection of fungal DNA. The supernatant was centrifuged at 13,000 $\mathrm{g}$ for $10 \mathrm{~min}$, and the pellet was washed with phosphate-buffered saline (PBS). Extraction and purification of Bacterial DNA were performed using Mora Extract (Kyokuto Seiyaku Co., Ltd., Tokyo, Japan). For fungal DNA, the buffy coat was washed twice with PBS and centrifuged at $3000 \mathrm{~g}$ for $10 \mathrm{~min}$ [6] [10]. The supernatant was decanted off and the pellet was reacted with $50 \mu$ of lysis buffer (COBAS ${ }^{\circledR}$ AMPLICOR S.E.T.S II Kit; Roche Diagnostics, Meylan, France) at room temperature for 2 min and then centrifuged at $1000 \mathrm{~g}$ for $1 \mathrm{~min}$. The pellet was again incubated with lysis buffer at $90^{\circ} \mathrm{C}$ for $20 \mathrm{~min}$, and then centrifuged at $13,000 \mathrm{~g}$ for $10 \mathrm{~min}$. Fungal DNA was extracted and purified from the pellet, using Mora Extract (Kyokuto Seiyaku). For amplification and detection of bacterial DNA the complete $16 \mathrm{~S}$ rRNA gene was amplified by PCR using two oligonucleotide primers: UN-F: 5'-CAG CAG CCG CGC TAA TAC-3' and UN-R: 5'-CCG TCA ATT CCT TTG AGT TT-3'. PCR reactions were carried out in a DNA thermal cycler (GeneAmp PCR System 9600; Applied Biosystems, Foster City, CA, USA) with preliminary denaturation at $95^{\circ} \mathrm{C}$ for $10 \mathrm{~min}$, followed by 45 cycles of amplification consisting of denaturation at $94^{\circ} \mathrm{C}$, primer annealing at $62^{\circ} \mathrm{C}$ and elongation at $72^{\circ} \mathrm{C}$, each lasting for $1 \mathrm{~min}$. For species identification, positive PCR products were sequenced using the ABI PRISM BigDye terminator cycle sequencing ready reaction kit and ABI PRISM 377 genetic analyzer (Applied Biosystems). For phylogenetic identification, sequences were compared with those of known bacteria listed in official databases using the BLAST program available at the National Center for Biotechnology Information (http://ncbi.nlm.nih.gov). For fungal DNA, the complete $18 \mathrm{~S}$ rRNA gene was amplified by PCR using two oligonucleotide primers: Fung-F: 5'-TTCGATGGTAGGATAGTGGCC-3 and B4R: 5'-TGA TCG TCT TCG ATC CCC TA-3'. This broad-range PCR system was able to detect a wide range of fungi other than Zycomycetes and Fusarium species. PCR reactions were conducted in a DNA thermal cycler with preliminary denaturation at $94^{\circ} \mathrm{C}$ for $5 \mathrm{~min}$, followed by 40 cycles of amplification consisting of $94^{\circ} \mathrm{C}$ for $30 \mathrm{sec}, 55^{\circ} \mathrm{C}$ for $1 \mathrm{~min}$, and $72^{\circ} \mathrm{C}$ for $1 \mathrm{~min}$. After amplification, all PCR products were precipitated by the addition of ethanol and amplified by nested PCR. The primers were designed to separate PCR products into groups based on their susceptibilities to antifungal agents. We used reacting systems for the group resistant to fluconazole (FLCZ) (Fung-F and n-Asp/Pen R:

5'-AGCCAGTGAAGGCCATG-3'), the group moderately resistant to FLCZ (Fung-F and n-C.glab-R: 5'-CCAACGGACAAGGACTTGG-3'), the group susceptible to FLCZ (n-Candida-F: 5'-TTTGATGCGTACTGGACCCA-3' and B4R), 
and a wide-range fungal group (n-Fung-F: 5'-GAATAAGGGTTCGATTCCGG-3' and n-Fung-R: 5'-CCCCGACCGTCCCTATTAAT-3'). The wide-range fungal PCR was simultaneously performed during second-round PCR to detect the small amounts of fungal DNA that could not be detected by first-round PCR and the sequence identified. We validated that the gene products amplified by the susceptibility primers were indeed derived from fungal DNA and obtained the same level of sensitivity to detect fungal species other than Candida spp., Aspergillus spp., and Penicillium spp. that were detectable by nested PCR with these susceptibility primers. The temperature conditions and number of cycles were the same as in the first PCR. Species were identified in any positive PCR products using the same methods as those used to identify bacteria. The positive controls for bacterial PCR were $100 \mathrm{CFU} / \mathrm{ml}$ of Staphylococcus aureus ATCC29213, $500 \mathrm{CFU} / \mathrm{ml}$ of Candida albicans JCM1542, $500 \mathrm{CFU} / \mathrm{ml}$ of Candida glabrata JCM1539, and $500 \mathrm{CFU} / \mathrm{ml}$ of Aspergillus fumigatus JCM1617. The negative control was nuclease-free water. When these positive and negative controls did not work as expected, we considered the assay invalid. We validated the bacterial and fungal PCR using 18 strains of 9 bacteria and 26 strains of 13 fungi (data not shown). The sensitivity of detecting fungus was $100 \mathrm{CFU} / \mathrm{ml}$ while that for bacteria was $50 \mathrm{CFU} / \mathrm{ml}$.

\section{Results}

\subsection{Molecular Detection of Bacteria}

Fifty-one PB samples from 10 patients were analyzed by bacterial PCR assays during the first month after ASCT (Figure 1). Bacteria were detected in 24 samples

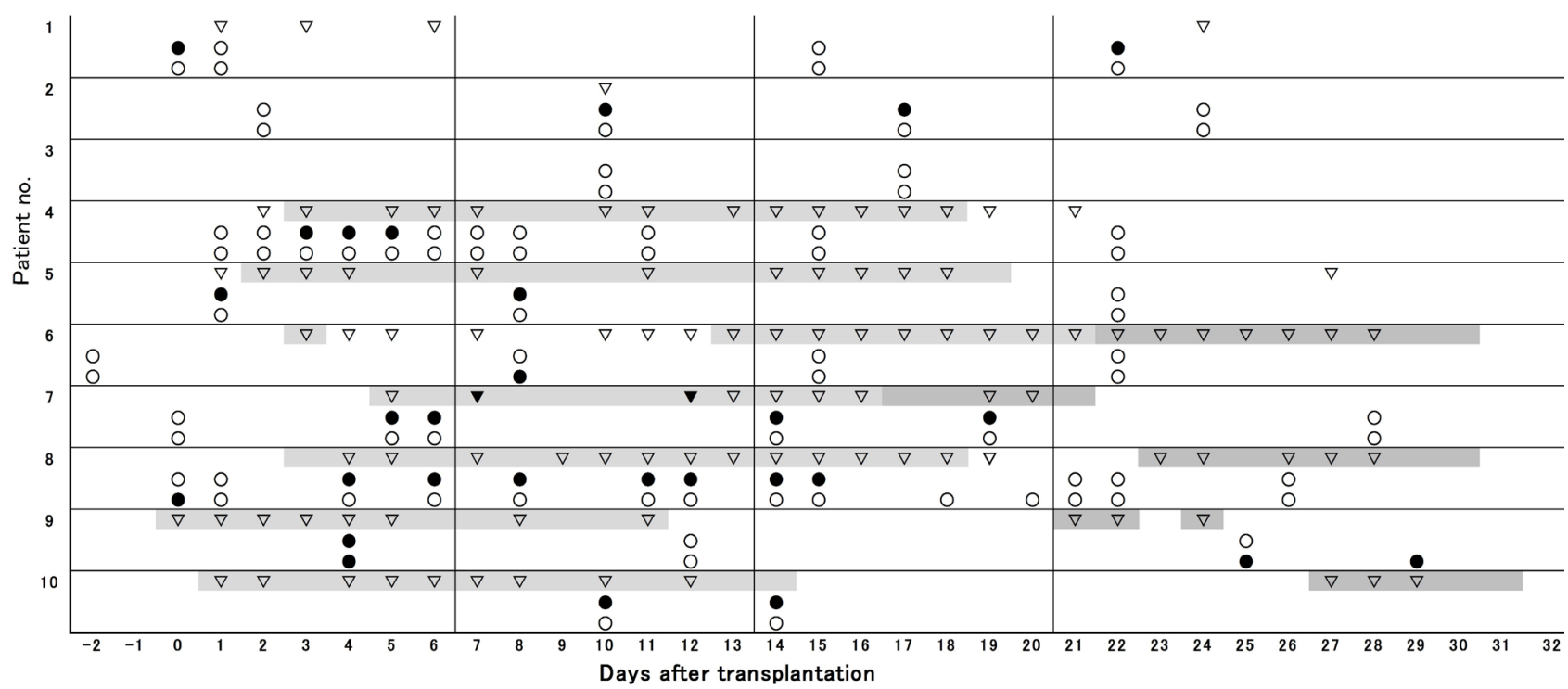

The upper row in each patient: $\nabla$ Blood culture $(+) ; \nabla$ Blood culture $(-)$. The middle row in each patient: PCR (-). The lower row in each patient: Fungal PCR (+); $\bigcirc$ Fungal PCR (-). Neutropenic fever; Bacterial PCR (+); $\bigcirc$ Bacterial to engraftment syndrome (all cases manifested regional skin eruption and a slight CRP elevation, which might include the symptom of GVHD in some cases).

Figure 1. Time course of bacterial and fungal PCR results in 10 patients. 
from 8 patients (Table 2). The species were identified in 17 samples; and 14 (82\%) were gram-positive cocci and 3 (18\%) gam-negative rods. In 7 positive samples from 3 patients (day 0 in patient 1, days $8,11,12,14$ and 15 in patient 8 , day 4 in patient 9), the bacterial species could not be identified because PCR products formed numerous bands. Multiple species in Table 2 indicates such cases, which were suspected of polymicrobial infections. Bacteria detected in 12 of 24 PCR-positive samples were considered to have originated from the oral cavity. Representative organisms identified were Streptococcus salivarius (days 3 5 in patient 4), Fusobacterium nucleatum (day 6 in patient 8), Abiotrophia spp. (days 10 and 17 in patient 2), and Streptococcus intermedius (day 8 in patient 5).

Table 2. Clinical characteristics of bacterial PCR positive cases.

\begin{tabular}{|c|c|c|c|c|c|c|c|c|}
\hline $\begin{array}{l}\text { Patient } \\
\text { no. }\end{array}$ & Bacterial PCR & $\begin{array}{l}\text { Day of PCR } \\
\text { positivity }\end{array}$ & Blood culture & Fever & $\begin{array}{l}\text { Stomatitis } \\
\text { (grade) }\end{array}$ & $\begin{array}{l}\text { Diarrhea } \\
\text { (grade) }\end{array}$ & $\begin{array}{l}\text { WBC counts on } \\
\operatorname{PCR}(+) \text { day }(/ \mu \mathrm{l})\end{array}$ & $\begin{array}{c}\text { Antibiotics used } \\
\text { during } \operatorname{PCR}(+) \text { days }\end{array}$ \\
\hline & $1^{\text {st }}$ week (day $0-6$ ) & & & & & & & \\
\hline 1 & multiple species & day 0 & - & - & 1 & 3 & 40 & $\mathrm{MEPM}+\mathrm{ABK}$ \\
\hline 4 & Streptococcus salivarius ${ }^{*}$ & day $3,4,5$ & - & + & 2 & 3 & $20,20,40$ & $\mathrm{CFPM}+\mathrm{VCM}$ \\
\hline 5 & Enterococcus species ${ }^{\star *}$ & day 1 & - & - & 2 & 3 & 20 & $\mathrm{MEPM}+\mathrm{VCM}$ \\
\hline 7 & Enterococcus faecalis ${ }^{* *}$ & day 5,6 & Enterococcus faecalis ${ }^{* * \star}$ & + & 0 & 3 & 30,20 & $\mathrm{MEPM}+\mathrm{VCM}$ \\
\hline 8 & Streptococcus bovis ${ }^{* *}$ & day 4 & - & + & 0 & 1 & 20 & $\mathrm{DRPM}+\mathrm{VCM}$ \\
\hline 8 & Fusobaterium nucleatum ${ }^{*}$ & day 6 & - & + & 2 & 1 & 10 & $\mathrm{DRPM}+\mathrm{VCM}$ \\
\hline \multirow[t]{2}{*}{9} & multiple species & day 4 & - & + & 2 & 3 & 430 & $\mathrm{MEPM}+\mathrm{VCM}$ \\
\hline & $2^{\text {nd }}$ week (day $7-13$ ) & & & & & & & \\
\hline 2 & Abiotrophia species ${ }^{\star}$ & day 10 & - & - & 1 & 0 & 90 & $\mathrm{MEPM}+\mathrm{ABK}$ \\
\hline 5 & Streptococcus intermedius ${ }^{\star}$ & day 8 & - & + & 3 & 2 & 50 & $\mathrm{MEPM}+\mathrm{VCM}$ \\
\hline 8 & multiple species ${ }^{*}$ & day $8,11,12$ & - & + & 2 & 0 & $20,50,90$ & $\begin{array}{c}\text { PZFX + VCM + } \\
\text { CLDM }\end{array}$ \\
\hline \multirow[t]{2}{*}{10} & MRSA & day 10 & - & + & 2 & 2 & 110 & $\mathrm{DRPM}+\mathrm{VCM}$ \\
\hline & $3^{\text {rd }}$ week (day $14-20$ ) & & & & & & & \\
\hline 2 & Abiotrophia species* & day 17 & - & - & 2 & 0 & 2870 & DRPM + TEIC \\
\hline 7 & $\begin{array}{l}\text { Stenotrophomonas } \\
\text { maltophilia }\end{array}$ & day 14,19 & $\begin{array}{l}\text { Stenotrophomonas } \\
\text { maltophilia }\end{array}$ & + & 0 & 1 & 210,4250 & $\begin{array}{c}\text { PZFX + VCM + } \\
\text { MINO }\end{array}$ \\
\hline 7 & $\begin{array}{l}\text { Staphylococcus } \\
\text { epidermidis }\end{array}$ & day 19 & - & + & 0 & 1 & 4250 & $\begin{array}{c}\mathrm{PZFX}+\mathrm{VCM}+ \\
\text { MINO }\end{array}$ \\
\hline 8 & multiple species* & day 14,15 & - & + & 2 & 0 & 350,570 & $\begin{array}{c}\mathrm{PZFX}+\mathrm{VCM}+ \\
\mathrm{CLDM}+\mathrm{ABPC} / \mathrm{SBT}\end{array}$ \\
\hline \multirow[t]{2}{*}{10} & MRSA & day 14 & - & + & 1 & 2 & 200 & $\mathrm{DRPM}+\mathrm{VCM}$ \\
\hline & $4^{\text {th }}$ week (day $21-27$ ) & & & & & & & \\
\hline 1 & Enterococcus species ${ }^{*}$ & day 22 & - & - & 0 & 1 & 4180 & DRPM + TEIC \\
\hline
\end{tabular}

$M R S A$ Methicillin-resistant Staphylococcus aureus, $W B C$ white blood cell, $M E P M$ meropenem, $A B K$ arbekacin, $C F P M$ cefepime, $V C M$ vancomycin, $D R P M$ doripenem, TEIC teicoplanin, PZFX pazufloxacin, $M I N O$ minocycline, $C L D M$ clindamycin, $A B P C / S B T$ ampicillin/sulbactam. ${ }^{\star}$ These bacteria considered to have originated from the oral cavity. ${ }^{* *}$ These bacteria considered to have originated from the intestine. ${ }^{* *}$ This bacterium was isolated on day 7 . ${ }^{* * *}$ This bacterium was isolated on day 12 . 
Multiple species detected in patient 8 seemed to also be of oral origin, as this patient suffered from stomatitis but not diarrhea. On the other hand, Enterococcus spp. (day 1 in patient 5, and day 22 in patient 1), Enterococcus faecalis (days 5 and 6 in patient 7) and Streptococcus bovis (day 4 in patient 8) were thought to have derived from the gut because of the presence of substantial diarrhea suggestive of intestinal mucosal injury. Concerning the other isolates: Stenotrophomonas maltophilia (days 14 and 19 in patient 7) and methicillin-resistant Staphylococcus aureus (MRSA) (days 10 and 14 in patient 10), their source remains to be determined. BC was performed on 106 PB samples, and bacteria were isolated from only 2 samples from one patient (patient 7 ). The isolated bacteria, E. faecalis (day 7 ) and $S$. maltophilia (day 12), were the same species identified by the molecular methods, although the detection timings of BC and PCR were slightly different.

Seven of 10 patients developed fever during neutropenic status after ASCT (Figure 1). Bacteria were detected by PCR in samples taken from 6 of these patients (patients 4, 5, 7, 8, 9 and 10). However, the remaining patient (patient 6) showed no molecular evidence of bacterial infection despite the presence of fever. Five of the 6 febrile patients showing bacterial PCR-positive results were manageable with empirical antibiotic therapies using broad-spectrum $\beta$-lactam plus glycopeptide without disclosure of the DNA data (Table 2). Among them, patient 7 followed a complicated clinical course, but the PCR results still did not need to be disclosed. At first, $S$. maltophilia was isolated by BC on day 12 during an empirical treatment with MEPM and VCM; thus, MEPM was changed to pazufloxacin (PZFX) plus minocycline. PCR detection of this bacterium continued (days 14 and 19) despite its disappearance from BC (day 13), and Staphylococcus epidermidis was additionally identified by PCR on day 19. However, the antibacterial therapy eventually contributed to clinical improvement. These repeated PCR detections could be explained by the levels of bacteria undetectable by BC or by already dead bacteria, and the detection of $S$. epidermidis may represent contamination due to normal skin commensals introduced during blood collection. In the case for which the PCR results were disclosed (patient 8), a high fever and CRP elevation developed on day 11 during empiric DRPM and VCM therapy, and we changed DRPM to PZFX plus clindamycin to cover anaerobes. But, as the fever continued, DNA data were at last disclosed to the physicians. PCR analyses on days 8,11 and 12 showed multiple species, but $F$. nucleatum had been identified on day 6; thus, ampicillin sulbactam was added on day 13 with a successful outcome. F. nucleatum may have been among the multiple species detected by PCR. Even in afebrile cases, bacteria were also detected by PCR in 5 samples from 3 patients (days 0 and 22 in patient 1, days 10 and 17 in patient 2, and day 1 in patient 5). These cases did not present any clinical problems, but still needed empirical antibiotic therapy for the symptoms of suspected infections.

\subsection{Molecular Detection of Fungi}

Fifty-four PB samples from 10 patients were analyzed by fungal PCR (Figure 1), 
and positive results were obtained in 5 samples from 3 patients (patients 6, 8 and 9) (Table 3). No fungi were isolated from BC of any PB samples. The fungal PCR-positive cases were manageable without disclosure of the molecular data. CT scans of patient 8 revealed several cavitary nodules in both lungs 12 days before ASCT. VRCZ had been given on suspicion of fungal infection, and these lesions disappeared just before preconditioning. The PCR data on day 0 identified Aspergillus fumigatus DNA, but at this time we were able to confirm the causal pathogen by PCR and to justify our VRCZ therapy. In patient 9, Candida crusei along with many other bacterial species were detected in a febrile situation on day 4. These organisms may have been derived from the gut, because severe diarrhea persisted at that time. This yeast was only temporarily detected and disappeared while we used prophylactic ITCZ. In this patient, Aspergillus niger was also identified by PCR during the afebrile period on days 25 and 29. Since the CT scan on day 17 had already shown an infiltration shadow in the right upper lung, we changed the antifungal from ITCZ (prophylactic use) to liposomal amphotericin B, which overcame the infection. The molecular information later corroborated the correctness of our antifungal management. In patient 6, Peliomyces lilacinus was transiently detected during an afebrile period and became undetectable during continuous prophylaxis with ITCZ.

\section{Discussion}

In this study, we performed broad-range PCR assays to detect a wide spectrum of bacteria and fungi to compliment the drawbacks of BC and evaluated the clinical usefulness of this system for planning BSI treatment during the first month after ASCT. Although PCR analysis proved far more sensitive than BC for the detection of both bacteria and fungi, most cases with PCR-positive results were manageable with empirical antimicrobial therapy alone and without the DNA data. This indicates that our PCR assay did not directly contribute to BSIs management early after ASCT. However, the PCR data seemed to provide etiologically

Table 3. Clinical characteristics of fungal PCR positive cases.

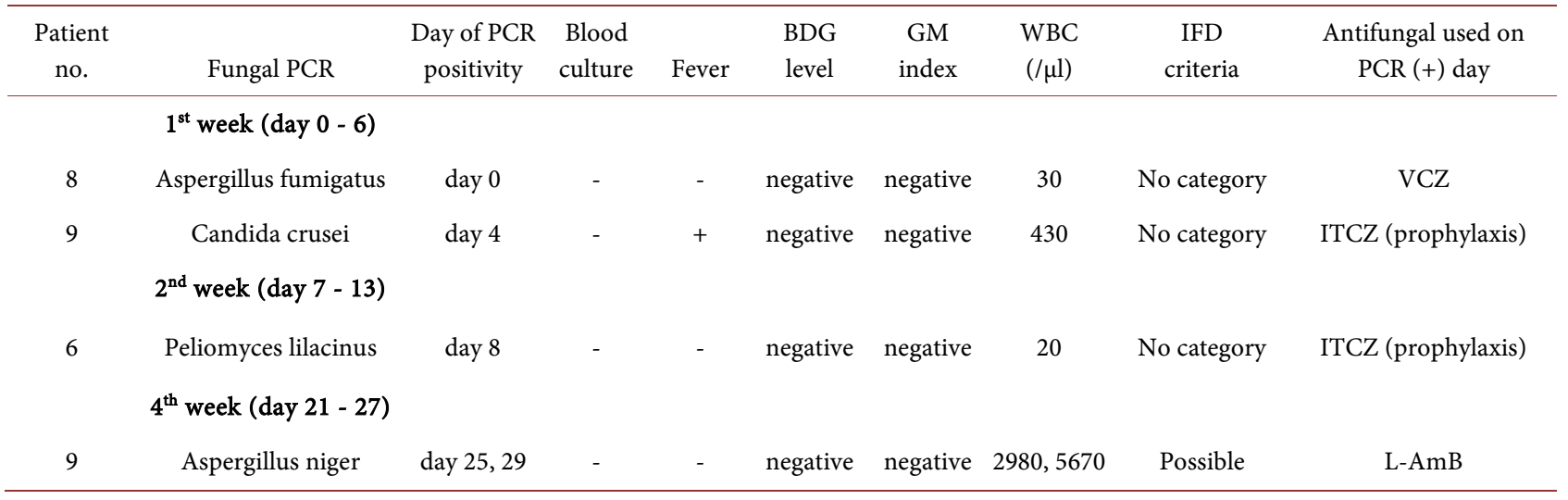

$B D G$ (1-3) $\beta$-D-glucan, $G M$ galactomannan antigen, $W B C$ white blood cell, $I F D$ invasive fungal disease, $V C Z$ voriconazole, $I T C Z$ itraconazole, $L$ - $A m B$ liposomal amphotericin B. IFD was classified according to the revised criteria of the European Organization for Research and Treatment of Cancer/Mycoses Study Group. 
valuable microbiological evidence.

As for the origin of bacteria identified by PCR, it is noteworthy that more than half of the organisms were considered to have originated from the oral cavity. In patients receiving intensive chemotherapy, not only neutropenia, but also treatment-induced mucosal injury appears to be crucial for the development of BSIs, and causative pathogens can originate from the endogenous microbiota inhabiting the mouth and the gut of the patients [11] [12]. Furthermore, severe oral mucositis occurs quite often in ASCT recipients due to the adverse effects of preconditioning with TBI [13] and cytotoxic drugs, such as high-dose cyclophosphamide and/or cytarabin [11], and the use of methotrexate containing GVHD prophylaxis [14]. Accordingly, BSIs due to orally derived organisms may develop more frequently in ASCT recipients than in patients receiving conventional chemotherapies. In addition, fluoroquinolone prophylaxis has been associated with an increased incidence of BSIs due to gram-positive bacteria, and oral viridans streptococci is one of among the most common blood stream isolates [15] [16], consistently with our observations. Orally derived bacteria appear to break into systemic circulation easily, because they do not pass through the major phagocytic system, such as the liver [17], and tend to be detected in PB with unexpected frequency compared to intestinal bacteria, as shown in our study. Since oral management is reported to effectively decrease the severity of stomatitis during ASCT [18] [19] [20], the same techniques should be evaluated for control of BSIs in ASCT recipients.

The other bacteria identified, E. faecalis [21], S. epidermidis [22], S. maltophilia [23] and MRSA [24], have also been described as orally derived pathogens in immunocompromised hosts. Since we performed DNA analyses only on PB samples and not on samples from mouth mucosa, we could not confirm their oral origin. However, such an origin seemed unlikely, as the former 3 species were detected in patients lacking stomatitis. In our study, contamination by exogenous microbes was distinguishable in most cases by the identity of the species, frequency of detection, and clinical evaluation. Transitory appearance of $S$. epidermidis was likely to be originated from contamination from the skin [25] [26].

The present study also demonstrated that all cases showing gram-positive bacteria in PCR were effectively treated by empirical therapy with glycopeptides [8]. To our knowledge, there have been no reports in which the effectiveness of this antibacterial strategy was confirmed etiologically based on molecular data from ASCT recipients.

Even in afebrile patients, PCR-positive results for bacteria or fungi were obtained in some cases. All such cases received empirical antimicrobial treatments due to observation of signs or symptoms of infection prior to PCR detection. Our findings suggest that preclinical or occult BSIs may continually occur in ASCT recipients regardless of the presence of fever. Further investigations are necessary to clarify the significance of the molecular identification of microor- 
ganisms in such cases.

In conclusion, although the molecular analyses did not directly contribute to manage BSI management early after ASCT, the DNA data were at least useful in elucidating the microbiological etiology of the BSIs. In addition, oral management appears to require a critical re-evaluation to reduce BSIs in ASCT recipients [18] [19] [20] [27]. However, as the main limitation of this study was the small number of cases examined, future large-scale studies will be required to validate our observations.

\section{Acknowledgements}

The authors thank all of the physicians and staff in the Department of Hematology and Oncology, Mie University Hospital, who assisted with the provision of data for this study.

\section{Conflicts of Interest}

The authors declare no conflicts of interest regarding the publication of this paper.

\section{References}

[1] Blennow, O., Ljungman, P., Sparrelid, E., Mattsson, J. and Remberger, M. (2014) Incidence, Risk Factors, and Outcome of Bloodstream Infections during the Pre-Engraftment Phase in 521 Allogeneic Hematopoietic Stem Cell Transplantation. Transplant Infectious Disease, 16, 106-114. https://doi.org/10.1111/tid.12175

[2] Kikuchi, M., Akahosh,i Y., Nakao, H., Ugai, T., Wada, H., Yamasaki, R., et al. (2015) Risk Factors for Pre- and Post-Engraftment Bloodstream Infections after Allogeneic Hematopoietic Stem Cell Transplantation. Transplant Infectious Disease, 17, 56-65. https://doi.org/10.1111/tid.12345

[3] Book, M., Lehmann, L.E., Zhang, X. and Stuber, F. (2013) Monitoring Infection: From Blood Culture to Polymerase Chain Reaction (PCR). Best Practice \& Research: Clinical Anaesthesiology, 27, 279-288.

https://doi.org/10.1016/j.bpa.2013.06.010

[4] Khot, P.D. and Fredricks, D.N. (2009) PCR-Based Diagnosis of Human Fungal Infections. Expert Review of Anti-Infective Therapy, 7, 1201-1221.

https://doi.org/10.1586/eri.09.104

[5] von Lilienfeld-Toal, M., Lehmann, L.E., Raadts, A.D., Hahn-Ast, C., Orlopp, K.S., Marklcin, G., et al. (2009) Utility of a Commercially Available Multiplex Real-Time PCR Assay to Detect Bacterial and Fungal Pathogens in Febrile Neutropenia. Journal of Clinical Microbiology, 47, 2405-2410. https://doi.org/10.1128/JCM.00491-09

[6] Nakamura, A., Sugimoto, Y., Ohishi, K., Sugawara, Y., Fujieda, A., Monma, F., et al. (2010) Diagnostic Value of PCR Analysis of Bacteria and Fungi from Blood in Empiric-Therapy-Resistant Febrile Neutropenia. Journal of Clinical Microbiology, 48, 2030-2036. https://doi.org/10.1128/JCM.01700-09

[7] De Pauw, B., Walsh, T.J., Donnelly, J.P., Stevens, D.A., Edwards, J.E., Calandra, T., et al. (2008) Revised Definitions of Invasive Fungal Diseases from the European Organization for Research and Treatment of Cancer/Invasive Fungal Inferctions Cooperative Group and the National Institute of Allergy and Infectious Diseases 
Mycoses Study Group (EORTC/MSG) Consensus Group. Clinical Infectious Diseases, 46, 1813-1821. https://doi.org/10.1086/588660

[8] Freifeld, A.G., Bow, E.J., Sepkowitz, K.A., Boeckh, M.J., Ito, J.I., Mullen, C.A., et al. (2011) Clinical Practice Guideline for the Use of Antimicrobial Agents in Neutropenic Patients with Cancer: 2010 Update by the Infectious Diseases Society of America. Clinical Infectious Diseases, 52, e56-e93. https://doi.org/10.1093/cid/cir073

[9] National Cancer Institute (2009) Common Terminology Criteria for Adverse Events v4.0. NIH Publication \#09-7473.

[10] Sugawara, Y., Nakase, K., Nakamura, A., Ohishi, K., Sugimoto, Y., Fujieda, A., et al. (2013) Clinical Utility of a Panfungal Polymerase Chain Reaction Assay for Invasive Fungal Diseases in Patients with Haematologic Disorders. European Journal of Haematology, 90, 331-339. https://doi.org/10.1111/ejh.12078

[11] Wardley, A.M., Jayson, G.C., Swindell, R., Morgenstern, G.R., Chang, J., Bloor, R., et al. (2000) Prospective Evaluation of Oral Mucositis in Patients Receiving Myeloablative Conditioning Regimens and Haemopoietic Progenitor Rescue. British Journal of Haematology, 110, 292-299.

https://doi.org/10.1046/j.1365-2141.2000.02202.x

[12] Blijlevens, N.M.A., Donnelly, J.P. and De Pauw, B. (2005) Prospective Evaluation of Gut Mucosal Barrier Injury Following Various Myeloablative Regimens for Haematopoietic Stem Cell Transplant. Bone Marrow Transplant, 35, 707-711. https://doi.org/10.1038/sj.bmt.1704863

[13] Robien, K., Schubert, M.M., Bruemmer, B., Lloid, M.E., Potter, J.D. and Ulrich, C.M. (2004) Predictors of Oral Mucositis in Patients Receiving Hematopoietic Cell Transplants for Chronic Myeloid Leukemia. Journal of Clinical Oncology, 22, 1268-1275. https://doi.org/10.1200/JCO.2004.05.147

[14] Cutler, C., Li, S., Kim, H.T., Laglenne, P., Szeto, K.C., Hoffmeister, L., et al. (2005) Mucositis after Allogeneic Hematopoietic Stem Cell Transplantation: A Cohort Study of Methotrexate- and Non-Methotrexate-Containing Graft-versus-Host Disease Prophylaxis Regimens. Biology of Blood and Marrow Transplantation, 11, 383-388. https://doi.org/10.1016/j.bbmt.2005.02.006

[15] Busca, A., Cavecchia, I., Locatelli, F., D’Ardia, S., De Rosa, F.G., Marmont, F., et al. (2012) Blood Stream Infections after Allogeneic Stem Cell Transplantation: A Single-Center Experience with the Use of Levofloxacin Prophylaxis. Transplant Infectious Disease, 14, 40-48. https://doi.org/10.1111/j.1399-3062.2011.00650.x

[16] Kimura, M., Araoka, H., Yoshida, A., Yamamoto, H., Abe, M., Okamot, Y., et al. (2016) Breakthrough Viridans Streptococcal Bacteremia in Allogeneic Hematopoietic Stem Cell Transplant Recipients Receiving Levofloxacin Prophylaxis in a Japanese Hospital. BMC Infectious Diseases, 16, Article No. 372. https://doi.org/10.1186/s12879-016-1692-y

[17] Nakase, K., Tsuji, K., Miyanishi, E. and Shirakawa, S. (1990) Pathogenesis of Fever of Unknown Origin in Patients with Acute Leukemia and Granulocytopenia. Medical Hypotheses, 33, 235-237. https://doi.org/10.1016/0306-9877(90)90133-Y

[18] Mori, T., Hasegawa, K., Okabe, A., Tsujimura, N., Kawata, Y., Yashima, T., et al. (2008) Efficacy of Mouth Rinse in Preventing Oral Mucositis in Patients High-Dose Cytarabine for Allogeneic Hematopoietic Stem Cell Transplantation. International Journal of Hematology, 88, 583-587. https://doi.org/10.1007/s12185-008-0181-5

[19] Da Silva Santos, P.S., Coracin, F.L., Barros, J.C., Dulley, F.L., Nunes, F.D., Magalhaes, M.G., et al. (2010) Impact of Oral Care Prior to HSCT on the Severity and 
Clinical Outcomes of Oral Mucositis. Clinical Transplantation, 25, 325-328.

https://doi.org/10.1111/j.1399-0012.2010.01283.x

[20] Yamagata, K., Arai, C., Sasaki, H., Takeuchi, Y., Onizawa, K., Yanagawa, T., et al. (2012) The Effect of Oral Management on the Severity of Oral Mucositis during Hematopoietic SCT. Bone Marrow Transplant, 47, 725-730. https://doi.org/10.1038/bmt.2011.171

[21] Baik, J.E., Choe, H.-I., Hong, S.W., Kang, S.-S., Ahn, K.B., Cho, K., et al. (2016) Human Salivary Proteins with Affinity to Lipoteichoic Acid of Enterococcus faecalis. Molecular Immunology, 7, 52-59. https://doi.org/10.1016/j.molimm.2016.07.013

[22] Soga, Y., Maeda, Y., Ishimaru, F., Tanimoto, M., Maeda, H., Nishimura, F., et al. (2011) Bacterial Substitution of Coagulase-Negative Staphylococci for Streptococci on the Oral Mucosa after Hematopoietic Cell Transplantation. Support Care Cancer, 19, 995-1000. https://doi.org/10.1007/s00520-010-0923-9

[23] Soga, Y., Saito, T., Nishimura, F., Ishimaru, F., Mineshiba, J., Mineshiba, F., et al. (2008) Appearance of Multidrug-Resistant Opportunistic Bacteria on the Gingiva during Leukemia Treatment. Journal of Periodontology, 79, 181-186. https://doi.org/10.1902/jop.2008.070205

[24] Ebinuma, T., Soga, Y., Sato, T., Matsunaga, K., Kudo, C., Maeda, H., et al. (2014) Distribution of Oral Mucosal Bacteria with mec4 in Patients Undergoing Hematopoietic Cell Transplantation. Support Care Cancer, 22, 1679-1683.

https://doi.org/10.1007/s00520-014-2151-1

[25] Costa, S.F., Micell, M.H. and Anaissie, E.J. (2004) Mucosa or Skin as Source of Coag Ulate-Negative Staphylococcal Bacteremia? The Lancet Infectious Diseases, 4, 278-286. https://doi.org/10.1016/S1473-3099(04)01003-5

[26] Kleinschmidt, S., Huygens, F., Faoagali, J., Rathnayake, I.U. and Hafner, L.M. (2015) Staphylococcus epidermidis as a Cause of Bacteremia. Future Microbiology, 10, 1859-1879. https://doi.org/10.2217/fmb.15.98

[27] Yamagata, K., Onizawa, K., Yanagawa, T., Hasegawa, Y., Kojima, H., Nagasawa, T., et al. (2006) A Prospective Study to Evaluate a New Dental Management Protocol before Hematopoietic Stem Cell Transplantation. Bone Marrow Transplant, 38, 237-242. https://doi.org/10.1038/sj.bmt.1705429 